\title{
Paulo Cesar Gonçalves. Migração e mão-de-obra: retirantes cearenses na economia cafeeira do Centro-Sul (1877-1901)
}

\author{
Rosângela Ferreira Leite*
}

São Paulo: Humanitas, 2006. 246p.

A importância das correntes migratórias e as formas de utilização de diferentes grupos de população nas lavouras do Centro-Sul do Brasil, no momento de crise do cativeiro, são temas recorrentes na historiografia brasileira.

O caso específico da transferência de migrantes cearenses, ainda no século XIX, para utilização nas plantações de café parece-nos, no entanto, um encaminhamento original ao estudo da organização da mão-de-obra no momento de superação da escravidão.

Paulo Cesar Gonçalves, retomando clássicas obras sobre a história do Brasil, enfrentou o desafio de compreender como foi se constituindo um mercado de trabalho no seio de um processo de reorganização econômica, permeado tanto por novas demandas de mercado, quanto pela construção de idéias que dessem suporte aos conteúdos políticos emergentes naquele momento.

Para responder a esses anseios, o autor fez uso de um espectro variado de documentação: por meio de listas da Hospedaria dos Imigrantes, relatórios de presidentes de província, ofícios da Secretaria da Agricultura, mapas estatísticos, livros de registro da Companhia de Vapores, anais do Parlamento e jornais de São Paulo, Rio de Janeiro e Ceará, constrói um quadro explicativo fincado sob os sentidos econômicos da migração dos retirantes cearenses, mas que não despreza, em momento algum, as propostas de civilização encravadas no bojo das medidas apresentadas pelos diferentes protagonistas da cena brasileira do período entre 1877 e 1901.

As secas do Nordeste funcionaram como um elemento desencadeador da expulsão dos cearenses de seus espaços originais, dos inchaços de cidades

\footnotetext{
* Centro de Ciências Humanas, Faculdade de História - Pontifícia Universidade Católica de Campinas (PUC/Campinas). Rodovia Dom Pedro I, km 136, Parque das Universidades. 13086-900 Campinas - SP - Brasil. rfl@usp.br.
} 
como Fortaleza e das conseqüentes medidas de envio desses livres pobres para o Centro-Sul. Os retirantes, no contexto de estiagem alarmante, tornaramse desprovidos de seus meios essenciais de subsistência, o que garantiu recolocação dessas populações de forma favorável - para setores da elite econômica - em novos espaços produtivos que possuíam demanda por trabalhadores.

Há que se considerar, no entanto, que esse processo não foi linear. A riqueza deste livro encontra-se exatamente na análise que permite compreender as contradições imanentes à utilização dos retirantes e, ao mesmo tempo, a depreciação da importância, por parte de alguns setores dirigentes, desses livres pobres no mercado de trabalho em formação.

Como diferentes grupos econômicos foram se articulando na crise do cativeiro? Como esses grupos poderiam incorporar os cearenses, preservando costumes patriarcais e relações de mando baseadas na violência? Essas são algumas das questões que Paulo Cesar Gonçalves procura discutir por meio desta obra.

Abordar as vicissitudes do processo de organização da mão-de-obra no momento de escravidão agonizante representa enfrentar a problemática sobre os sentidos da (re)elaboração das idéias acerca da Nação no período de declínio tanto do Império, quanto do trabalho escravo. O autor apresenta duas respostas importantes a tais questões. Para ele, a circulação das populações permitiu e, ao mesmo tempo, foi fruto de um processo de proletarização por meio do qual foram se constituindo mãos-de-obra disponíveis. Esse processo favoreceu, efetivamente, a organização dos trabalhadores para os cafezais como fenômeno que se deu fora dos limites geográficos São Paulo. Por esse viés interpretativo, a organização produtiva funcionava como componente central para o emprego adequado de diferentes grupos humanos de acordo com os interesses dominantes à época. Nesta mesma chave explicativa, o trabalho livre e baseado em relações permeadas por salário só pôde se constituir no Brasil pela interlocução entre as necessidades produtivas, variantes a cada momento, e as relações sociais fortemente assentadas na coerção de diferentes grupos de trabalhadores.

O século XX, iniciado pouco após a proclamação da República, recolocou velhos problemas à sociedade brasileira, muitos deles ligados à questão de como gerir contradições latentes às relações de trabalho num mundo de recente passado escravista e completamente dominado pelas relações capitalistas.

As formas e os conteúdos dessas contradições são matéria-prima para os estudos sobre as populações livres pobres. O livro de Paulo Cesar Gonçalves apresenta-se como uma importante referência nesta ceara de debates.

Resenha recebida em dezembro de 2006. Aprovada em dezembro de 2007. 